\title{
Why is the Dollar So High?
}

\section{Citation}

Feldstein, Martin. 2007. Why is the dollar so high? Journal of policy modeling 29, no. 5: 661-667.

\section{Published Version}

Http://dx.doi.org/10.1016/j.jpolmod.2007.06.002

\section{Permanent link}

http://nrs.harvard.edu/urn-3:HUL.InstRepos:2794833

\section{Terms of Use}

This article was downloaded from Harvard University's DASH repository, and is made available under the terms and conditions applicable to Other Posted Material, as set forth at http:// nrs.harvard.edu/urn-3:HUL.InstRepos:dash.current.terms-of-use\#LAA

\section{Share Your Story}

The Harvard community has made this article openly available.

Please share how this access benefits you. Submit a story.

\section{Accessibility}


NBER WORKING PAPER SERIES

WHY IS THE DOLLAR SO HIGH?

Martin Feldstein

Working Paper 13114

http://www.nber.org/papers/w13114

\section{NATIONAL BUREAU OF ECONOMIC RESEARCH}

1050 Massachusetts Avenue

Cambridge, MA 02138

May 2007

An earlier version of this paper was presented at the 2007 meeting of the American Economic Association. The views expressed herein are those of the author(s) and do not necessarily reflect the views of the National Bureau of Economic Research.

(C) 2007 by Martin Feldstein. All rights reserved. Short sections of text, not to exceed two paragraphs, may be quoted without explicit permission provided that full credit, including $\odot$ notice, is given to the source. 
Why is the Dollar So High?

Martin Feldstein

NBER Working Paper No. 13114

May 2007

JEL No. F3,F32

\begin{abstract}
$\underline{\text { ABSTRACT }}$
The level of the dollar is part of a complex general equilibrium system. Nevertheless, it is helpful to recognize that the high level of the dollar is necessary to generate the current account deficit equal to the difference between national saving and investment. Understanding the high level of the dollar therefore requires understanding the reasons for the low level of national saving in the United States. Reducing the large current account deficit will require both a higher rate of national saving and a more competitive dollar. Although the necessary decline in the real value of the dollar can in theory occur without a decline in the dollar's nominal value, the implied magnitude of the fall in the domestic price level is implausible. A decline of the real value of the dollar that is large enough to reduce the current account deficit significantly requires a significant decline in the nominal value of the dollar.

Martin Feldstein

President and Chief Executive Officer

NBER

1050 Massachusetts Avenue

Cambridge, MA 02138-5398

msfeldst@nber.org
\end{abstract}




\section{Why is the Dollar So High?}

Martin Feldstein*

Although there is no natural measure of how high a currency is, the magnitude of the U.S. trade and current account deficits makes it clear that the dollar is very high relative to a long-run equilibrium level. The trade deficit in 2006 was about $\$ 750$ billion or nearly six percent of GDP and the current account deficit was some $\$ 100$ billion larger. These enormous deficits are unprecedented for the United States or for any other major industrial country.

In attempting to explain why the dollar is so high it is necessary to begin by recognizing that the dollar is one price in the complex general equilibrium system that describes the global economy. The level of the dollar is influenced by and in turn influences the interest rates, the trade volumes, and the levels of saving and investment, to name only some of the key variables. However, while this is clearly true, it doesn't help to understand the fundamental process of dollar determination.

A more useful way to explain the high level of the dollar is to note that the dollar must be this high to generate a trade deficit ${ }^{1}$ equal to the difference between national investment and national saving. The basic national income accounting identity tells us that investment minus saving equals imports minus exports. If

*Professor of Economics, Harvard University, and President of the National Bureau of Economic Research. These remarks were presented at the 2007 meeting of the American Economic Association.

${ }^{1}$ Technically, the current account deficit that includes both the trade deficit and the net investment deficit. I will use the term trade deficit as a convenient short hand. 
saving is low relative to the investment (in plant and equipment, inventories and housing), we must have a trade deficit to bring in the resources to fill the gap. While many things influence the size of the trade deficit, the level of the dollar is one of the key determinants. Given an approximately full employment level of income at home and abroad and given the tastes of domestic and foreign consumers, the dollar is the key determinant.

This line of reasoning leads us to the low level of the U.S. saving rate as the primary cause of the high level of the dollar. The national saving rate includes business saving and government saving as well as the saving of households. Business saving (i.e., corporate retained earnings) is quite high, reflecting the strong level of profits. The fiscal deficit is relatively small at less than 2 percent of GDP. It is the low and falling level of household saving that is keeping national saving so low and thereby causing the saving-investment gap, and, in turn, the need for a high dollar to generate an equivalent trade deficit.

Personal saving as a percentage of disposable personal income has been falling in the United States since the beginning of the 1990s. At that time, personal saving was about 7 percent of disposable personal income. It declined gradually until it reached just 2.3 percent of disposable income in mid-2003. It then dropped sharply over the next two years to a negative minus 1.5 percent of disposable income. It remains at about that level now.

Two primary forces have been driving down the household saving rate: increasing wealth and, more recently, mortgage refinancing. The value of portfolio 
wealth has increased as share prices have risen, with the S\&P index in real terms 120 percent higher now than in 1990, a period during which real GDP rose only 60 percent. Even more striking has been the rise in the value of owner occupied housing. The value of that housing stock (divided by the consumer price index) rose even faster with a greater rise in the real value of the housing stock net of mortgage debt.

Individuals who are saving for retirement can rightly conclude that, because of these wealth increases, they can afford to save less. And retirees who are dissaving can look at their wealth and conclude that they can afford to dissave relatively more than previous generations of retirees. This has progressed to a point where the depressed saving of the savers and the increases dissaving of the dissavers has caused the net saving rate to be negative.

In addition to the effect of rising wealth, saving has recently been depressed by a surge in mortgage refinancing. When the Federal Reserve responded to its concern about the possibility of deflation by lowering the federal funds rate to 1 percent and promising to raise it only slowly, the long term rates fell, including the rates on long term mortgages. Since households can pay off and refinance their mortgages without penalty, many households did just that. They repaid their existing mortgages by borrowing at new lower interest rates. Because of the rising value of their homes, they were able to borrow more than the amount needed to repay their existing mortgages. Some of the extra funds that they extracted in this way were reinvested in financial assets but some were used to purchase consumer durables or spent on home improvements. Although the individuals might have 
regarded such spending as a form of investment, these outlays are treated as consumption in the national income accounts.

It is natural to ask why the low rate of saving did not reduce the rate of investment by a corresponding amount. As Charles Horioka and I showed many years ago (Feldstein and Horioka, 1980), countries with a sustained low saving rate tend to have a low rate of investment. But that is a relationship that holds over decade long periods. In the short run, a decline in saving generally leads to a capital inflow to maintain the previous level of investment (Feldstein, 1983).

More specifically, the rate of investment continued at a relatively high level because the fall in saving did not cause the rate of interest to rise. The rate of interest did not rise because of the large availability of capital from abroad. Three sources of such capital inflow have been particularly important. First, the Chinese government stabilized the exchange rate between the dollar and the rinminbi by buying large volumes of U.S. Treasury securities, thus keeping down the interest rate on those bonds. Second, the Bank of Japan has pursued a low interest strategy, with the short rate close to zero. This encouraged private individuals in Japan and abroad to borrow yen, sell the yen for dollars, and invest the funds in dollar securities. This “yen carry trade” kept US rates lower than they would otherwise have been. And the rapid rise in the price of oil has created large amounts of investable funds in the oil producing countries which have been temporarily invested in dollar securities.

$\underline{\text { Reducing the Trade Deficit }}$ 
What will it take to reduce the U.S. trade deficit? Reducing the trade deficit requires an increase in the U.S. saving rate or an equally large fall in business investment and residential construction. I believe that the adjustment will come primarily through a higher saving rate and that this will happen without any specific change in government policy. The household saving rate will rise because the two primary forces that have driven savings down will come to an end. First, the sharp rise in wealth caused by abnormal gains in share prices and house prices will not continue. Home prices are already beginning to decline and the prices of stocks are not likely to outperform earnings in the future in the way that they did in the past. Second, the mortgage refinancing will not continue to generate spendable cash for households as it has in the past. The decline in mortgage refinancing has not yet begun. But at a certain point there will be very few households with mortgage rates that exceed the rates available on new mortgages. There will also no longer be a stock of net equity that can be accessed by borrowing.

The increase in saving (or, more accurately, of saving relative to investment) is a necessary condition for reducing the trade deficit but it is not sufficient. Households and businesses in the United States and abroad must be given an incentive to spend more on American made goods and services and less on the goods and services made elsewhere in the world. That incentive, of course, is a change in the relative prices of American and foreign goods and services. The way in which this will come about is a decline in the value of the dollar relative to the value of other major currencies - the euro, the yen, the Chinese RAB, the British pound, etcetera. When the dollar declines relative to the euro, as it has been over 
the past year, American goods are cheaper relative to European goods. That makes American households and businesses buy less in Europe and more in America. And the same happens in reverse for European buyers.

It is, of course, possible in theory for the relative prices of American and foreign goods to change without any change in the nominal exchange rate. If the prices of all American goods and services were to fall by (say) 20 percent while the exchange rates remained unchanged, that would achieve a 20 percent real devaluation of the dollar. That would have the same effect as a 20 percent fall in the nominal exchange rate while the prices of US and foreign goods remained unchanged (or rose together as the same rate). There is, of course, no chance that U.S. prices would actually fall by anything like that. Similarly, while a 20 percent rise in all foreign prices would also cause such a change in the real exchange rate if nominal exchange rates remained unchanged, there is no chance of such an inflationary shift now that most countries are managing monetary policy to keep inflation very low. In short, changing relative prices will require a change in the nominal exchange rate.

Some people worry that even a large decline in the value of the dollar would not be able to change purchasing patterns enough to reduce the U.S. trade deficit. It is common to hear the concern that the U.S. no longer has the ability to manufacture and export. Or the worry that we will never be able to compete with the low labor costs that drive imports from countries like China or Vietnam.

Both of these worries are unfounded. The U.S. is a major exporter, selling 
more than $\$ 1$ trillion of goods to the rest of the world in the past 12 months. And as a lower dollar causes the price of those goods to become more competitive relative to the goods made in other countries, our exports will rise more rapidly. Caterpillar tractors compete with the Komatsu tractors made in Japan. Boeing airplanes compete with European airbus planes. California wine competes with wine from France, Italy and Spain. And as the dollar declines, these U.S. products will be mor e attractive to buyers at home and abroad.

About half of our imports come from high-wage countries including Canada, western Europe and Japan. A lower dollar relative to those currencies will cause a substitution of American-made goods for the similar goods that we import from abroad.

But what about the goods that come from countries in which wages are very low? It is certainly true that American workers will not be able to compete in the production of such low-cost goods. We will not see American factories making the products which are now produced in very low cost factories in some Asian countries. But instead of substituting American-made goods for very similar imports, the lower dollar will cause Americans to buy a different mix of goods and services that are produced in the United States.

As the dollar declines relative to the Chinese yuan, the Korean won, and the Thai bhat, the dollar prices of those products will rise. American consumers will find them less attractive and will shift to buying U.S. goods and services. Much of that substitution will be to services which can only be produced in the U.S. For 
example, as imported t-shirts and sneakers become more expensive, American consumers will spend more on meals away from home and on travel in the United States.

The Sticky Dollar

Why has this not happened already? Why has the saving rate not increased and the dollar declined? I have already explained the special conditions that have caused the saving rate to remain low: rising wealth and continued opportunities to refinance mortgages. The continued high value of the dollar is more of a puzzle.

As I noted at the beginning of these remarks, the low saving rate creates a natural pressure for an overvalued dollar. But if the dollar were to fall before the saving rate declined, the level of aggregate demand in the U.S. would rise (more exports, fewer imports). That would push up interest rates, causing business investment and housing construction to decline and speeding up the end of mortgage refinancing. This would shrink the current saving-investment balance and provide room for the increased net exports induced by the decline of the dollar.

A decline of the dollar would naturally be driven by the combination of an expectation that the dollar must fall to shrink the trade deficit and the small difference between interest rates on dollar bonds and euro denominated bonds. Financial investors who believe that the dollar must fall over the next few years at an average rate that exceeds the interest differential between US and foreign interest rates should prefer to hold foreign bonds. That portfolio shift should occur 
until the dollar reaches a level at which further falls are no larger than the prevailing interest difference. The difference between dollar interest rates and the interest rate on similar European securities is now less than one percent. So, an investor who believes that the dollar will decline by more than one percent a year should want to hold foreign bonds rather than dollar bonds.

Why has that not occurred? Why has the dollar declined only slowly relative to the euro and the pound and hardly at all relative to the Japanese yen and the Chinese yuan? A variety of forces have delayed the full adjustment of the dollar. The most obvious of these has been the massive intervention policy of the Chinese government that is designed to prevent an appreciation of the yuan and the resulting loss of competitiveness of Chinese products in global markets.

Although economists generally agree that a country cannot use exchange rate intervention to prevent the eventual decline of an overvalued currency (because they lack sufficient foreign exchange reserves to offset sustained foreign selling of their currency), a government can depress its own currency by supplying more of it. The Chinese have responded to the large trade surpluses and investment inflows by buying dollars for yuan and then sterilizing the increased money creation. In this way, the Chinese have accumulated more than $\$ 1$ trillion of foreign exchange reserves, mostly dollar assets. That buying of dollar bonds has strengthened the dollar and offset the effect of those who would shift dollars to yuan in anticipation of a fall of the dollar relative to the yuan.

The government of Japan now follows a different strategy to stimulate 
exports by depressing the value of the yen. Until a few years ago, the Bank of Japan engaged in massive currency market intervention, effectively buying up surplus dollars that came to Japan as a result of its trade surplus and investment inflow much as the Chinese now do. More recently, this intervention ended and was replaced by a more traditional policy of depressing the currency by maintaining a very low rate of interest. With short term interest rates close to zero, it was and is attractive for investors to borrow yen, then convert that yen into dollars on which they can earn a higher interest rate. The interest difference has been as high as five percentage points, implying that an investor who borrows yen and lends dollars will gain, as long as the dollar does not fall by more than five percent during the year. This "yen carry trade” has been a major source of demand for dollars, keeping the dollar artificially high.

In addition to these government policies, the dollar has been supported by private investors whose strategy does not accurately reflect the risks and returns of their investments in dollars. Although many investors in the foreign exchange markets may be sophisticated, there is substantial evidence of trading based on socalled momentum strategies (“The trend is your friend.”) and other false views about this market.

There are at least four examples of these "false views." First is the belief that the U.S. government favors a strong dollar and would take steps to reverse a dollar decline. U.S. Treasury secretaries for at least the past 15 years have repeated the mantra that a strong dollar is good for the United States . In fact, the Treasury department has taken no steps to resist or reverse the fall of the dollar against the 
euro and the pound. A no-intervention policy seems a more accurate description of the likely future policy as well.

Second is the belief that the trade deficit can be eliminated without a decline of the dollar. The statements of eminent economists and widely read financial journalists reinforces this view. As I have already noted, this is theoretically feasible but would require implausibly large movements of the price level in the United States and our trading partners.

The idea that the trade and current account imbalances can be corrected without a change in exchange rates is reinforced by the rhetoric of the International Monetary Fund that point to the need to reverse global imbalances and then describe what it believes will be needed to bring that about: higher saving in the US, increased productivity in Europe, more investment in the OPEC countries, and greater exchange rate flexibility by the Chinese. A general adjustment of the dollar relative to all currencies is not mentioned. The same is true of the pronouncements of the G-8 and other official bodies.

A third source of confusion is the belief that the current level of the dollar may be satisfactory because "the U.S is an attractive destination for private investments and therefore has no trouble financing its trade deficit at this level of the dollar." The evidence for this position comes from the monthly reports of the U.S. Treasury department (the Treasury international capital reports) that appear to show that the capital inflow often exceeds the trade deficit and that these funds are coming from private investors. 
Neither inference is warranted by the actual evidence. Since the U.S. government does not intervene in the foreign exchange market, the monthly capital inflow must exactly equal the size of the current account deficit that needs to be financed. Any difference between this current account deficit and the Treasury report's measure of the capital inflow simply reflects the fact that the Treasury data exclude certain forms of capital movements, including non-financial foreign direct investment, short term portfolio investments and bank loans and deposits. So there is no evidence in the Treasury reports about the ease or difficulty in financing the trade deficit.

The classification of the capital inflow as coming from private sources is also misleading because transactions are classified according to the nature of the transactor, rather than of the ultimate source of funds. When the government of an oil producing country buys U.S. Treasury bonds through a British bank, the transaction is recorded as a purchase by a private British buyer.

These widely reported monthly statistics no doubt convince some investors, as they appear to convince the journalists who report these numbers, that the U.S. attracts large volumes of private capital because of the attractiveness of investing in the United States economy. In fact, the funds that come to the U.S. now are almost exclusively in the form of bond purchases rather than equity inflows and therefore, given the small interest difference, are likely to be primarily government funds rather than private investors.

Fourth, market participants focus on very short term conditions rather than 
longer term fundamentals. The trade deficit and the growing exposure of foreign investors to dollar assets should persuade investors that the dollar will have to fall by more than the small interest differential - but much of the movement of the dollar exchange rate responds to short term shifts in economic conditions that are expected to cause small changes in interest rates.

I believe that all of these forces that are supporting the dollar will change in the period ahead. The Chinese are unhappy with their large dollar exposure and are committed to increasing domestic consumption as the way to maintain aggregate demand and increase employment. The Japanese see their economy improving and will allow interest rates to rise. More importantly, the investors who are pursuing the yen carry trade will increasingly recognize that this is a risky strategy in which the appreciation of the yen relative to the dollar may outweigh the interest differential. The four false views about the sustainability of the current exchange rate will change as investors learn more about each of these issues and as they see the dollar decline relative to major currencies.

The primary risk going forward is that the decline of the dollar and the rise of the saving rate will happen at different speeds, leading to domestic imbalances. If the dollar falls while the saving rate remains very low, the increase in net exports will cause a rise in interest rates and a decline of fixed investment and other interest sensitive forms of spending. This narrowly focused decline of demand would be more destabilizing to the economy than a rise in net exports balanced by a broad-based decline in consumption. 
Alternatively, if the saving rate rises significantly without a corresponding decline of the dollar the reduction in consume spending will cause a general decline in U.S. aggregate demand and a rise in unemployment. Because of lags between the dollar decline and the rise of net exports, the domestic weakness will occur unless the dollar decline precedes the rise in saving.

Weakness of the U.S. economy would eventually cause the dollar to decline unless foreign governments seek to protect their own net exports by policies that prevent a rise in the value of their currencies, either by intention or by the pursuit of an expansionary monetary policy rather than a fiscal policy. The perception that foreign governments are preventing a recovery of the U.S. economy by such policies would exacerbate already troubling rise in protectionist sentiment in the United States.

The best hope for a smooth adjustment of both the global and U.S. imbalances would be a substantial fall of the dollar followed by a significant rise in the U.S. saving rate and a policy of fiscal stimulus in other countries. Achieving this will require both good policies and good luck. 


\section{$\underline{\text { References }}$}

Feldstein, Martin (1983) "Domestic Saving and International Capital Movements in the Long Run and Short Run,” European Economic Review 21 (1-2) pp 129-51

Feldstein, Martin and Charles Horioka (1980) “Domestic Saving and International Capital Flows,” Economic Journal, 90 (358) pp 314-29 